Bigger Than Ourselves: The Southgate narrative and the search for a sense of common purpose.

\begin{tabular}{|r|l|}
\hline Journal: & Sport in Society \\
\hline Manuscript ID & FCSS-2020-0071.R2 \\
\hline Manuscript Type: & Original Article \\
\hline Keywords: & $\begin{array}{l}\text { Banal Nationalism, Englishness, Football, Progressive Patriotism, } \\
\text { Imagined Community }\end{array}$ \\
\hline
\end{tabular}

SCHOLARONE $^{\text {M }}$
Manuscripts $^{\text {Manusion }}$ 


\section{Bigger Than Ourselves: The Southgate narrative and the search for a sense of common purpose.}

\section{Introduction}

For a few beautiful, long weeks as the anticipation and pride and expectation kept building up, we came together in a way we hadn't for a while. There were mosques draped with the England flag. There were Hindu mothers and young Muslim boys doing faux-prayers in front of the TV. We shared memes, laughs and songs of 'it's coming home' in countless multicultural settings. We showed that pride in England can be expressed in lots of different ways. (Hundal 2018)

At the time Hundal was writing the opening quote about more expansive forms of nationalism in the summer of 2018, the England manager, Gareth Southgate, made an unusual claim during his team's memorable run to the World Cup semi-finals:

We have the chance to affect something bigger than ourselves. We are a team with our diversity and with our youth that represents modern England. In England we've spent a bit of time being a bit lost as to what our modern identity is and I think as a team we represent that modern identity, and hopefully people can connect with us. (Rosser 2018)

Up until this point, England managers had not tended to place their teams' achievements in a wider socio-cultural-political context, apart from periodically excusing inaction against racism in football on the basis that racism was a problem of society, not football. Southgate's argument - that his side reflected a particular version of national identity, representing something that was bigger than football was not, it is true, an entirely new one. Ever since England's goalless draw with Scotland in 1872, the first ever official international football match to be played, the national team have been viewed as a powerful force for shaping England's sense of itself as a nation. It has been frequently presented, alongside the cross of St George, the Royal Family, the works of Shakespeare and St George's Day, as a symbol of quintessential Englishness. And certainly, since the pre-millennial angst of the 1990s (the decade Southgate began his playing career and made the bulk of his international appearances as an England player) the team's performances have taken on a heightened, state-of-the-nation significance. Whatever else seems to be happening in the affairs of the nation, whether it be a war, political upheaval or a referendum exposing deep divisions, a large part of the population appears to come together for a few weeks every two years to invest its emotions in an international football campaign. 'Short of war', Ellis Cashmore was quoted as commenting (Doward 2018), 'there's no more effective way of galvanising English identity than football against another nation. When the England team is involved in a big game, the clock of history seems to stop.'

What we look to do in this paper is to consider two 'turns' in national sporting culture, 'Beckhamisation' (after David Beckham the England captain between 2000 and 2006) and 'Southgatism'. Both have been presented as new dawns of new eras, and we shall examine the values they represent. We do this against the backdrop of 
everyday representations of football and associated elements of footballing culture, particularly music and the flag.

Assertions of the relationship between sport and national identity abound in academic literature (see for example, Bairner 2001, 2015) and Billig (1995 120) identifies it as a domain in which the 'commonplace stereotypes of nation, race and place' are repeated. Moreover:

The (re-)production of identities is further enabled through ritualised sporting spectacles in international settings, by everyday consumption of nationally framed sports media and by diverse practices of fandom and spectatorship. (Brentin \& Cooley 2015, 2)

Indeed, Giulianotti $(1999,23)$ observes that, 'at internationals, the team embodies the modern nation', pointing out like Hundal that this involves 'often literally wrapping itself in the national flag'. By the 1996 European Championships, which we consider in more detail later, that national flag had become the cross of St George (red cross on white ground) rather than the Union Flag to distinguish Englishness from Britishness.

In this paper we utilise the concept of the nation as an imagined community (Anderson 1983), though not taken here as a specifically political project but as a cultural representation produced by quotidian actions. In this regard sport provides a space in which this 'imagined community' can be not just consumed, but performed and thereby re-produced. Duke and Crolley (1996) have observed that it is in pitting nation against nation that football best represents imagined communities. This is in line with Billig's (1995) concept of banal nationalism. He refers to this as 'embedded in routines of social life' (175), or what Edensor (2002) refers to as the nationalism of everyday life, and Hearn (2007) as the micro-level creation and re-creation of national identity. It is at this level that we can best appreciate the intersectional elements (music, sport, media, merchandise) that construct the cultural imaginary. Skey (2009) argues that it is through banal signifiers (like the accoutrements of football) that national identity is reproduced in the everyday, 'continually reminding of us and them' (Billig 1995, 175) and sometimes underpinning more virulent aspects of nationalism (a theme to which we shall return).

The focus of research on the performance of Englishness is typically on fans (e.g. Crabbe 2004), but through modern media this imagined community is not limited to football fans but re-presented in the everyday lives of the wider population. Cowley and Shaw (2019) concede that 'in some ways, all nations are imaginary constructs', but still imply that an imagined community is inadequate, somehow not 'real'. On the contrary, it is the way in which national identity is produced and re-produced. In that respect the trappings of sport, music, flags, language, multi-cultural representation, team ethos and espoused values are not just signifiers, but have a pivotal part to play in representing, repressing and resisting particular forms of Englishness. We note Kersting's (2007) conclusion from the 2006 FIFA World Cup, hosted by Germany, that the event contributed to a specific German 'sport patriotism' that promoted tolerance, equity, multiculturalism and democracy, rather than xenophobia. However, we note also that he questions the sustainability of that new German patriotism which had emerged during the World Cup. With this in mind we look to interpret the meaning-makings associated with the repeated representations and discussion of the England national football team and how these have evolved. We 
do this, of course, aware that any presumption of a singular English identity is misplaced and note Gibbons' $(2011,875)$ conclusion that 'specifically English articulations of identity were not homogenous among English football fans', partly because they 'have overlapping affiliations' (876); they are not simply 'English'. Considering football paraphernalia we are also alert to his challenge to 'commonsense notions that the increased display of specifically English symbols marks the beginnings of a unified English national project that will follow the path of the other now devolved nations within the UK' (876).

The paper will argue that Southgate's own story arc, from his playing days in the 1990 s to his current role as national coach, provides us with an illuminating, and at times challenging, insight into the formation of such a narrative. It is meant to be a starting point for a discussion of the way the construction and telling of the Southgate narrative - let us call it 'Southgatism' - has emerged as the latest attempt to define English 'modern identity' in an era when music has taken on a special significance in the perception and reception of the England men's team. More specifically, his own footballing journey, from his infamous penalty miss against Germany in 1996 to his managerial experiences two decades later, can be viewed as something of a counter-narrative to the overblown claims of the preceding, all-singing-all-dancing, hubristic, glamorous New Era for which we shall adopt the term, the 'Beckhamisation' of Britain. We consider how Beckhamisation and Southgatism evidence both change and continuity in the national identity supported by banal nationalism.

Our account relates only to elite male football; we do this in response to its position in media representation, discursive practices and national consciousness. Billig himself (1995), in identifying the significance of sport in constructing nationalism, says that it has historically been a largely masculine domain. We recognise the recent strides made in advancing women's sport, but suspect that though the form may differ similar processes of banal nationalism are at play there too. How women's football contributes to and is shaped by this discourse is certainly worthy of examination, but currently the contribution of men's football to shaping national identity is far greater if only because of the media attention it commands. Within the academic framework of banal nationalism we place emphasis on the work of media commentators, largely because they have collectively had a greater role in reflecting and shaping the national debate than have academic papers in the same field and are therefore embroiled in banal nationalism. As Anderson recognised, newspapers play a significant part in reminding 'readers' of national identity, contributing to national consciousness that is developed by shared experiences; and international sport, even if mediated, provides a suitable vehicle for that.

\section{Music in Football}

Just as we are not the first to draw attention to the link between sport and nationalism, we are not the first to consider the role of music within sport (apart from papers in this and Bateman's issue in 2014, see also Kyto, 2011; Turner, 2013). Appearing, the year after the 2018 World Cup campaign, on a television documentary commemorating England's 1,000th game ${ }^{1}$, David Goldblatt 
differentiated 'us' from others: "It's not through opera, it's not through classical music, it's through football that the English have somehow ended up constructing and telling giant parts of their national narrative". This is true, but it is also true that music, whether in an elite form such as opera or through more accessible outlets such as pop music and crowd singing and chanting, has often played an important role as the soundtrack to that narrative: indeed, Kyto (2011) refers to this as an acoustic community. Braginsky (2014) offers a Russian example in line with Anderson's idea of a clearer political project, as do songs that support feelings of persecuted nationalism as represented by 'Keep St. George In My Heart'. However, Hill (1999, 16) contended that 'English identity is the least precise of all the domestic nationalisms' on the basis that 'there is no direct equivalent of Scotland the Brave or Cwm Rhondda'. Indeed, some of the fans later interviewed by Gibbons (2011) 'mentioned the choice of the [Football Association] to continue to use the British national anthem God Save the Queen instead of a more specifically English one' as one of their grievances (874). Others would undoubtedly have been delighted and others just did not care, but in the absence of a specific national anthem, other songs assume greater significance.

Assessing the football stories the English have told about themselves over the previous quarter of a century, Goldblatt (2014) suggested that 'football, for all its intense moments of collective ecstasy, is also about narrative'. He identified 1990 as the watershed year when a new narrative of Englishness began to emerge, in a new era of (what was to become, after 1992) Premiership football, all-seater stadiums and a highly commercialised approach to the game. This era, when style triumphed over substance and elite footballers entered a new stratosphere - derided by some for their bloated arrogance, celebrated by others as global style icons - was also a new one for the England men's football team. It was associated with a soundtrack of many songs. It might be seen to have started with New Order's 1990 World Cup song World in Motion featuring a rap by John Barnes, and followed by a succession of others including Vindaloo, Keep St. George In My Heart, The Dambusters' March and the theme tune to the film The Great Escape. The first of those is a football chant parody; the second is beloved of the Far Right, including the Football Lads Alliance; and the last two are references to World War Two, which ended in Europe in 1945. However, two in particular have stood out over the period: Nessun Dorma and Three Lions (It's Coming Home).

Southgate made his England debut in 1995, five years after the 1990 World Cup in Italy when Nessun Dorma had established itself as the mood music for football's hugely-hyped reinvention. Clearly it was not the lyrics that secured its status among England supporters (few of the English public have any idea what they are, apart from the climactic 'Vincero'), but the desire to be associated with 'a touch of class', heralding a new era for England fans. This can be recognised as the same kind of search for distinction and affirmation of identity that Long (2013) has written about in a different sporting environment; the signifier might be read as 'we are not quite the hoi polloi you imagine'.

The very different Three Lions ${ }^{2}$ that became a number one single was penned by the Britpop band, the Lightning Seeds and the comedians Frank Skinner and David Baddiel. It was written for Euro 96 (football's European Championships) at a time when England appeared to be emerging from the wilderness years in terms of 
international football. The Three Lions (Football's Coming Home) song struck a chord with a populace hoping for better times and a new generation of England fans eager to celebrate their country hosting its first major football tournament since the 1966 World Cup while at the same time referring to the bittersweet existence of following a team which always just came up short. As Aughey (2007) observed, it celebrated the tournament being an opportunity for the English to reassert their national identity in a self-confident and agreeable way. However, we think it necessary to introduce a level of complexity to that analysis.

During the 1998 World Cup campaign, a remix of Three Lions portrayed Paul Ince (the first Black player to have captained England) as a hero for his bloodied shirt in the crucial qualifying game in Italy: 'And now I see Ince ready for war/Gazza good as before/Shearer certain to score/And Psycho screaming' ran the lyrics. As Katwala (2019) wrote of the 1996 European Championships, there were 'concerted efforts from fans to change the culture, triumphing in the Football's Coming Home spirit with which England hosted the European Championship'. Volunteering in the 'Raise the Flag' initiative, coordinated by Philosophy Football he was involved in giving supporters white and red cards to make a giant St George's Flag in the stands. He observes that the intended message was, 'yes to national pride and an inclusive patriotism, but no to racism'. Katwala also noted that 'part of this very English initiative involved putting out cards at the other end for opposing supporters to raise their own flag, including a short explanation of this gesture in, say, Swedish too'.

For the likes of Katwala it might have symbolised a new, anti-racist patriotism but several critics have dismissed the 'It's Coming Home' mantra as a chimera. Despite initial optimism Williams (2018) has argued that far from helping patriotism lose its stigma, the song 'refers to a pre-multicultural England: a reactionary appeal, perhaps, to a time when there were no black faces in the England team and few in the crowd'. It was a time when the football chant that gave Paul Gilroy (1987) the title for his book, There Ain't No Black in the Union Jack, was still raw. As Williams asked: 'Is the phrase a thinly disguised and rather uncomfortable call for a return to a more monochrome and mythologised version of England's past glories?' Those of course were glories built on the colonialism of the British Empire and an idea of the innately superior mother country.

Such was the song's prominence in the zeitgeist that Tony Blair, wound up his speech at the Labour Party annual conference by cannily rebranding New Labour's project with this mood music. The then-leader of the opposition, and soon to be prime minister, picked two key phrases out of the Three Lions song book to argue that Labour was 'coming home', after seventeen 'years of hurt' (Conservative rule).

\section{The Beckhamisation Thesis}

In the 1990s it was argued that The Dark Ages of football were over. A decade earlier, The Sunday Times (19/5/85) had described the sport, as a 'slum sport played in slum stadiums increasingly watched by slum people', and, as Puccini's soaring aria, accompanied by Paul Gascoigne's uncontrollable sob during the Italia 90 semifinal between England and West Germany, was endlessly dissected by philosophers, cultural historians and TV pundits, a brave new world was announced, one that would transfigure the national landscape, both on and off the pitch. In 1996, the year 
Southgate missed from the penalty spot in another semi-final defeat to Germany, the country was about to go New Labour, the Premier League was about to go global, and the 'people's game' was about to embrace a new culture of soaring TV fees, billionaire foreign owners and flashy, pampered prima donnas. It was this set of processes that we argue should be characterised as the Beckhamisation of Britain; the wealthy football star had married a wealthy pop star (as had fellow England international, Jamie Carragher) and enjoyed celebrity status.

Meanwhile, Tony Blair's call for the "classless" modernisation of his party and the UK echoed the Football Association's 1991 document Blueprint for the Future of Football, which argued that football should follow the affluent middle-class consumer. The ' 90 s did indeed mark a change in the social composition of football crowds, a shift from unskilled and manual workers to the higher paying skilled and professional classes. After a landslide victory in 1997, Blairism helped shape a re-imagined Britain, embracing the glamour, glitz and gated luxury of a so-called Cool Britannia (Campbell and Khaleeli 2017), described by Curtis (2019):

This was the era when football was adopted by the middle classes thanks to Nick Hornby, David Baddiel and David Beckham, amongst others. When [Damien] Hirst, Charles Saatchi and Tracey Emin pushed contemporary art onto the front pages. When British fashion became a serious force thanks to figures like Alexander McQueen, John Galliano, Rankin and Kate Moss. It was also a period in which an unholy alliance grew between PR and the media, celebrities and brands, which sowed the seeds of what was to come.

As in the 1960s London was brandished as the cultural capital of the world: Lad Culture reigned supreme, Britpop chart battles were promoted by the tabloid media and the Golden Generation of modern-day football superstars (from Beckham, Michael Owen and Steven Gerrard through to Rio Ferdinand, Frank Lampard and Wayne Rooney) seemed to be a portend of English football's imminent 'homecoming'. This 'homecoming' was part of the Cool Britannia myth which fed into the New Labour narrative of reversing national decline.

Lawton (2013) argued that Beckham's own career was 'notable for genius selfpromotion' and an 'uncanny understanding of celebrity culture...Beckham has been the man of his times, the quintessence of fame'. By 2006, the English football game's Beckhamite rebranding appeared to be complete. 'Every great English banana-skin moment at a major tournament is a ritual that marks the passing of time', wrote Kuper (2018), 'and celebrates a certain idea of England'. Towards the end of the decade that re-branded English football, two notorious banana-skin moments - the 1996 Southgate penalty miss and the 1998 Beckham sending off stopped the clock of history and brought into sharp focus the differences between the under-appreciated Southgate and the over-hyped Beckham. The way Beckham emerged from his banana-skin moment was an illustration of what O'Toole (2018) identified as a combination of 'airy haughtiness' and 'dejected resignation'; it reflected a national narrative 'caught between the conviction of superiority and the feeling of impotence'.

This fluctuation between airy haughtiness/superiority and dejected resignation/impotence was also a feature of the New Labour era (1997 to 2010). 
New Labour, like the New Football Order created in the 90s, lost touch with its traditional heartlands, allowing itself to be caricatured as being run by a self-serving elite. As we have said, football and music had been important in New Labour's search for a new version of patriotism. Blair had thrown his weight behind England's bid to host the 2006 World Cup, with Beckham taking a central role in the failed campaign, and five years later the same pairing was prominent in the successful bid for London to host the 2012 Olympic and Paralympic Games. At a Labour Party conference held between Euro 96 and the 1997 election, the future prime minister had played keepy-uppy with Newcastle manager Kevin Keegan. His inner circle's bible was Nick Hornby's Fever Pitch not Karl Marx's Das Kapital (Parker 2008). Hornby's best-selling memoir touched a nerve. It sold over a million copies in the UK and launched a thousand football fan confessionals. Traditionalists denounced the genre as yet another example of the Great Sell-Out, the commercialisation and gentrification of the working man's game.

\section{Flaws in the Beckhamisation Thesis}

Even the unlikely figure of key New Labour strategist Peter Mandelson attempted to capitalise on football's growing popularity, telling his local paper it was 'so important' for his constituents that 'his' local football team (Hartlepool) avoided relegation. He was brought down to earth, however, when he turned up at a match wearing a knitted blue-and-white football scarf, thrown Oxbridge-style over his shoulder, only to be regaled by his fellow supporters with the chant: "Who's the wanker in the scarf?"3 Newcomers might be good for the finances of the game, but they are still expected to observe the customs of fandom to show they are part of the imagined community (Spracklen, Timmins and Long 2010).

Although presenting itself as an era which would decisively banish the Dark Ages forever, there were two major flaws in the attempt to 'Beckhamise' English football, indeed Englishness itself.

The first flaw has been an overemphasis on the importance of an individual saviour and the attendant celebrity culture. Since the emergence of Paul Gascoigne in the Nessun Dorma World Cup (1990), an increasingly hyper-commercialised, and hyperbolised, game has been obsessed with hyper-inflating the idea of a poster boy, a super-hero, a shining knight in armour, a greatest-and-most-charismatic-footballerof-his-era, to sell its overblown narrative of Englishness to a global market. The sublimely-talented Tottenham Hotspur midfielder was the first to be canonised in such a way. In the London Review of Books Karl Miller (1990) compared him to 'a priapic monolith in the Mediterranean sun' and in a subsequent Granta essay, entitled Gazza Agonistes, lan Hamilton (1993) compared the player to a Miltonic Old Testament hero. From this moment, other young superstars-in-the-making, from Michael Owen to Wayne Rooney, were successively imbued with similarly preposterous expectations. They were breathlessly built up by both tabloid and broadsheet newspapers, and then inevitably knocked down, inspiring fans and writers alike into delusional flights of fancy, triggering national prayers for metatarsal and other injuries, all the time masking the glaring structural deficiencies in English football.

Even when the up-and-coming superstar in question (again inevitably) ended up 
tarnishing his brand, a narrative of redemption would quickly be introduced. With Owen, it was his extortionate wages and a perceived flashy lifestyle; for example using a helicopter to fly back and forth from Newcastle United's training ground. With Rooney it was an early-career sex scandal and, a bit later, his sending off against Portugal in the 2004 World Cup quarter-final. With Beckham, of course, it was his red card against Argentina in the 1998 French World Cup. This 'moment of madness' which condemned the England men's team to another painful exit led to an effigy being hung outside a London pub, his face being printed on a tabloid dartboard, multiple death threats and other excessive reactions. Beckham's petulance in that game typified, for some of his critics, the swaggering entitlement of his generation.

In embodying an emergent celebrified culture, Beckham's career came to be seen as an emblem of a Golden Generation of players who prioritised individual, and club, glory over national unity. Reflecting on this club-before-country tendency a few years after his retirement, Beckham's former Manchester United team-mate Rio Ferdinand claimed it had sabotaged England's chances at major tournaments. Referring to his cohort of world-class stars like Beckham, Steven Gerrard, Frank Lampard and Paul Scholes, Ferdinand said: 'It overshadowed things. It killed that England team, that generation' (Machell 2018). He explained how club loyalties and commercial interests frustrated the development of an identity for the national team. While much of the nation was invested in its national team, it seems the players were not.

Beckham famously redeemed himself when his curling, last-gasp free-kick against Greece sent England to the 2002 World Cup finals. The game's spin doctors subsequently used his 'journey' - from Public Enemy Number One to the poster boy of the New Football - as another marketing hook to attract TV, sponsorship and corporate deals. But this club-before-country phenomenon - in an era when the elite clubs they played for were becoming cash cows, mega-brands, disconnected from their fan bases - reached its apotheosis in the 2006 World Cup when, at the behest of Beckham himself, wives and girlfriends were allowed by Eriksson to stay in an opulent hotel in Baden-Baden. The Swedish coach, the first foreigner to take charge of the England men's team, was a famously relaxed manager. His off-field romances became part of a national debate about the changing face of football and his indulgence of Beckham's celebrity lifestyle was blamed for what one commentator, referring to the 2006 World Cup, described as 'a three-week spousal circus of conspicuous consumption and competitive drinking' (Derbyshire 2018). At that moment, the Baden-Baden Wags, partying like rock stars, seemed to denote a latetwentieth-century, celebrified England.

The second flaw of Beckhamisation lies in the continuation rather than the demise of bigotry and xenophobic nationalism. As Carrington $(2004,2)$ observed:

A powerful narrative emerged during the men's 2002 FIFA football World Cup finals that suggested that England had managed to emerge from its hibernation within the shell of British nationalism and had constructed a postimperialist, non-white multicultural formation in which all - white, black, brown, male, female, gay, straight - were now included. This post-Gazza construction of white English masculinity has a new face in the so-called meterosexual, multi-signifying persona of David Beckham; wearer of sarongs 
and lover of R \& B music, yet dutiful family man and caring father, and still a hero to the terraces.

Yet like us, Carrington disputes the idea that Beckhamisation represented a brave new liberated and multi-cultural version of the nation and its team.

The Premier League was marketed from the start as a new, cosmopolitan, postracist 'product', launching an era which consigned bigotry, along with hooliganism (known across the footballing world as 'the English disease') and the game's other demons, to the dustbin of history. The pre-1990s game had been a pariah, it was argued, not only because it was a 'slum sport' but also due to its grounds often being rallying points for xenophobic nationalism. The 1980s had been the apotheosis of a shameful era that was scarred by three appalling tragedies (Heysel, Bradford and Hillsborough). The following decade brought all-seater stadiums, better stewarding, a new, more middle-class fan base and the post-Heysel return to European football. It also, according to Goldblatt (2014), brought an end to 'the idea that one could hitch the notion of white racial nationalism to the England football team and its fans'.

Unfortunately, Goldblatt's optimism was premature. Chants such as "If it wasn't for the English, you'd be Krauts" and "No surrender to the IRA" were still, in this supposedly transformative decade, part of the England supporters' repertoire. The legacy of an exclusionary nationalism was not so easily denied. The campaign, Let's Kick Racism Out of Football (the precursor to Kick It Out) began in 1993 as a challenge to a succession of high-profile events and routinised behaviour, most conspicuously the bananas and monkey chants. Following his selection to play for England in 1982, Cyrille Regis received a letter containing a bullet and a warning against ever playing for his country at Wembley. Two years later, after John Barnes had scored an outstanding goal for England against Brazil (Brazil 0, England 2), National Front supporters took to singing "We only won one-nil", on the basis that to their mind goals scored by Black players should be disregarded.

The appointment of Paul Ince as the first black player to captain the England men's football team in 1993 was heralded as an important symbolic moment, feeding into a New Football Era narrative which attempted to draw a line under the xenophobia of the "two world wars and one World Cup" era. Again, it was a piece of music, New Order's 1990 World Cup song World in Motion featuring the famous John Barnes rap, which came to epitomise this supposedly post-racist moment. A simple binary was presented in a discourse dominated by the new generation of Hornby-influenced football obsessives, in which the dark days of the 1980s were effortlessly, and unproblematically, replaced by the sunny uplands of the 1990s. Racism, it was claimed, was a thing of the past. A brand new era was being established, one that would transfigure the country's footballing, and political, landscape.

However, 1993 was also the year England's then coach Graham Taylor came under FA pressure, he later claimed at a lunch for Kick It Out, not to go beyond a certain limit in the number of black players selected (Onuora 2015) ${ }^{4}$. That was also the year John Major ${ }^{5}$ (prime minister), a big fan of cricket, offered his nostalgic image of 'the real' England that was implicitly white: 'long shadows on county grounds, warm beer, invincible green suburbs, dog lovers and pools fillers'. Three years later, at Euro 96, 
when a new, more inclusive, sense of national pride was supposedly invoked in the song Three Lions (Football's Coming Home) the sudden appearance of St George's flags and carnival costumes, noted Goldblatt (2014), 'sent ripples of anxiety through the black press, where there remained considerable unease with the notion of Englishness. The lingering air of racism in stadiums discouraged minority ethnic football fans from joining the crowd in the early 1990s.'

The fact that Three Lions composers, the Lightning Seeds, were a Britpop band seemed apposite. As Carrington has highlighted, New Labour was keen to benefit from the reflected glory of Britpop. Noel Gallagher of Oasis appeared on the front cover of New Labour New Britain (Autumn 1996) and the centre-fold trumpeted 'New Labour, New Britpop'. The feature lauded Britpop 'for having shown that British bands have transcended the musical influences of (black) America and have found their own distinctive voice' (Carrington 1998a, 105). Carrington continues by arguing that:

The promotion of Britpop serves to reinvent a racially exclusive version of British cultural history, both ignoring, or down-playing, the musical debts to black culture of British pop music from the late 1950s onwards and denying the cultural diversity of contemporary Britain'. (Carrington 1998a, 105)

The 'it's coming home' lyric can be criticised for invoking a vestigial race memory of Britain's imperial past, and in any case there is some doubt that 'the English' invented modern football. Although FIFA, the game's international governing body, insists the current codified form of the sport was established in England in 1863 (the first written laws, the first national football federation and the first organised cup and league competitions), earlier versions can be traced much further back to China and it became a folk activity across Europe from the late-medieval period (Westall 2016). Despite being suspicious of FIFA and continental interpretations of the game, the game's ruling bodies in England clearly helped spread football around the world. For Carrington (1998a, 112/3):

The (Three Lions) song's repeated use of the chorus 'football's coming home' fits neatly into the wider (Britpop) political discourse and reinforces the ethnocentric notion that football is returning to its rightful place, back into the national psyche of England...'football's coming home' is, then, essentially about trying to reconstruct an imperial Britain, with the assumption that, no matter what others may say about football being a world game, England somehow has inalienable rights to the game... football is essentially our game.

Even by the time of the 2002 World Cup, Garland's $(2004,79)$ reading of events was that although 'a new, more inclusive Englishness was evolving amongst England supporters, this was not reflected in associated tabloid coverage, where a narrower and more nostalgic Englishness was commonly observed'. By 'nostalgic' he implies a reactionary, exclusionary nationalism, akin to Carrington's $(1999,84)^{6}$ assessment that racism can be represented as an 'expression of authentic English nationalism'. Garland's analysis of tabloid coverage of the competition was that:

English identity was a temporary, contingent phenomenon that could be given 
and taken away, depending on context. Perhaps for some of the tabloids minority ethnic Englishness was acceptable within the footballing arena where there are so many successful African Caribbean players'. (91)

One might say 'minority ethnic Englishness was acceptable' while they demonstrated assimilation by adopting the flag of St George, singing Football's Coming Home, wearing the replica shirts and supporting the national team; a very contingent form of nationalism, dependent upon the adoption of banal signifiers.

\section{Southgatism: a new dawn?}

The argument of this paper is that 'Southgatism', in providing more nuanced claims on what England can be, has been part of an attempt to address both these flaws.

Southgate is alert to the nuances and complexities of national identity in a cosmopolitan age and can talk about them with more sophistication than most politicians. He understands how patriotism can, indeed must, be a progressive cause rather than serve as a proxy for a darker, more unpleasant nationalism. Southgate also understands how in a multicultural country we can find greater unity through diversity, so long as we share a sense of common purpose.

Cowley and Shaw 2019)

What was new with Southgate's claim that his side reflected a particular version of national identity, was the strange occurrence of an England manager transcending the confines of his traditional prosaic remit and presenting his team, in the words of Cowley and Shaw, as 'a mirror in which we see the nation reflected back at us'; to acknowledge the off-the-pitch power of football to influence, as Southgate ${ }^{7}$ put it, 'our modern identity'; to recognise, indeed embrace, his team's ability 'to affect other things that are even bigger (than) football results'.

In the same television programme mentioned earlier Goldblatt praised Southgate for having made 'more accurate and more nuanced and more supportable claims on what England can be and what our position in the world is than most of our politicians'. Goldblatt and others on that programme argued that Southgate's vision of the team, his narrative of modern Englishness, seemed to strike a chord with a country badly bruised by Brexit and its attendant polarisation. It was at a time when the government was pursuing an agenda of creating a 'hostile environment' for immigrants and reported racist incidents were on the rise (Booth, 2019).

It is our argument that the practical, down-to-earth, level-headed realism of Southgate's managerial regime has been a reaction to the failure of the Golden Generation. As Goldblatt (2014) writes, this 'new wave of players, nurtured in the elite clubs of the Premier League' was first identified by FA chief executive Adam Crozier in 2001.

He pinpointed 2006, when in terms of age they would be around their collective peak, as England's best chance to win the World Cup. In fact they were eliminated, again on penalties, in a quarter-final... At the moment that the boom years of New Labour came to an end and the financial bubble popped, the stock of the golden generation was properly evaluated and found 
to be oversold and overrated.

The 'nothing else mattered' ethos of the Golden Generation was anathema to Southgate. Instead of the never-ending search for an individual saviour, Southgate's ethos has been side before self every time. As a player, Southgate saw himself as a character actor rather than a bill-topper. Born in Watford in 1970, the son of an IBM employee and teacher, he was a solid, dependable, skilful defender who spent three years as manager at Middlesbrough battling against limited resources before quietly, and successfully, running the England under-21 side for another three years. The jokey Pizza Hut advert in 1996, in which he appeared with bag over his head after missing the penalty against Germany, was typical of his self-deprecation. His playing career had been a successful but relatively low-profile one; although a brilliant career in many respects, it could never have been accused of being 'oversold and overrated' in the manner of the golden generation. There were no stars in his 2018 World Cup squad. England captain Harry Kane was a key figure, but his image was the opposite of Beckham's; he was engaged to an old schoolfriend rather than a pop star and refused to cover himself in tattoos because "my dad always told me I would regret it when I was older".

During the era of Beckhamisation football had become as lopsided as the economy. Following the 2008 banking collapse, the economic gap between north and south grew even wider and at the same time large swathes of the country felt themselves to have been disenfranchised by a global footballing order perceived to be out of touch and capricious. Interestingly, Southgate's 2018 squad represented an important geographical, as well as racial, diversity. Six of the squad were from Yorkshire which was significant for a county which, in its poorer, left-behind areas, voted overwhelmingly to leave the EU: a two-fingered riposte to what they saw as a London-based establishment, detached from life beyond the capital.

More importantly, Southgatism has come to represent a third way ${ }^{8}$ between haughtiness and resignation, treating those two sporting impostors, triumphalism and defeatism, with equal disdain. It was, perhaps, a response to the new sensibilities of the 2008 financial crash, representing a dampening down of expectations, a more modest, sensible, self-deprecating idea of Englishness. In this sense it reflected an alternative to the triumphalist/despairing contradictory narrative of Englishness: thoughtful, unflashy, inclusive. His idea of England, of modern English identity, does not simply reflect a grittier, more down-to-earth country. It also embraces, indeed takes a stand on, diversity by attempting to construct and tell a 'more accurate and more nuanced and more supportable' version of 'what England can be and what our position in the world is'.

Whether wittingly or not, this aspect of the Southgate narrative requires a reexamination of the 'post-racist' mythology of the Cool Britannia era. '[Southgate] revealed [in the 2018 World Cup] a sophisticated understanding of the complexities of what it means to be English in an age of upheaval', argued a $2018 \mathrm{New}$ Statesman editorial on footballing patriotism, which continued:

After the bitterness and divisions of the Brexit referendum, Mr [sic] Southgate, through his dignity and humility, has shown a different face to the world: what we might even call the beginnings of a new progressive Englishness. 
In order to construct and tell this new version of Englishness, Southgate, in his press conferences and interviews, has constantly recognised that a significant amount of work still needs to be done to rid the national game of its own problem with racism. To give just two examples: at the time of writing not a single Premier League manager is black, despite a third of all the competition's players being from BAME backgrounds; and only four managers out of 92 clubs in the four English leagues are from BAME backgrounds.

Some 30 years after World in Motion, during England's away win over Bulgaria in October 2019, two songs appeared to confirm the consolidation of this 'post-racist' era. These songs from the stands - "You racist bastards, you know what you are" and "Who put the ball in the racists' net? Super Raheem Sterling" (Ronay, 2019) were responses to the monkey chants and racist abuse being directed at three England players, including Raheem Sterling, by a section of the crowd. During the game Nazi salutes had been made and the 50-strong group of black-clad ultras who were behind some of the abuse were ejected. Those tabloids which, three decades earlier, had been accused of stoking xenophobic sentiment were the first to praise the anti-racist chanting and 'call out' the Bulgarians. The Daily Express put 'England Stand Up To Racist Fans' on their front page. Referring to Sterling's goal, Jones (2019) wrote in The Sun:

It was the best way he and his team-mates could hit back...The mindless minority brought shame on Bulgaria... It was deeply distressing simply to watch, to feel the skin crawl whenever one of England's black players had the ball in anticipation of what might happen and so goodness knows how Mings, Sterling and Rashford were able to continue.

The magazine for left-of-centre intellectuals, the New Statesman (2018), joined in the praise, identifying 'a sense of common purpose' around the Bulgarian match. 'exemplified by [Southgate's] multiracial players, whose fortitude and togetherness were apparent during and in the immediate aftermath'.

Director of think tank British Future, Sunder Katwala, who describes himself as a member of the Anglo-Irish-Indian diaspora, preferred a more differentiated approach. On the one hand, he saw the near-identical coverage in the tabloids and broadsheets as showing a broad consensus on anti-racism norms, 'at least when it comes to the overt racism of monkey chants and Nazi salutes', putting:

....a real nail in the coffin for the old National Front, and their heirs and successors: the now-defunct BNP, the thugs of Britain First and the trendier efforts to make racism fashionable again, ethno-nationalist groups like Generation Identity. Today, the argument about ethnicity and Englishness has been mostly won: 90 per cent of the population do not think you need to be white to be English - up from 80 per cent seven years ago. (Katwala 2019)

At the same time he cautioned against a misplaced sense of superiority suggesting Bulgaria should catch up with the progress we have made here on racism (note Billig's [1995] observations on how such words are used to flag banal nationalism). It is certainly to soon to consider the mission to challenge racism in UK football and 
society to have been accomplished. As Katwala observes, 'it is much harder to make the case for race equality and equal opportunity once the lens is widened to the dug-out, the press box and the boardroom'. He insists, 'there remains racism in England, within sport, and especially beyond it'.

This echoed the more nuanced approach adopted by Southgate himself. Just as in the 2018 World Cup he had noted that football was 'bigger than ourselves', he now argued that the events in Sofia transcended the confines of everyday football discourse. With no 'official' England World Cup song the fans were still wedded to Three Lions. However, Southgate implicitly challenged the tabloids' attempt to revive the feel-good, it's-coming-home discourse of the 1990s, when sport (football in particular) was uncritically promoted as a metaphor for a new version of Englishness. He insisted that any denunciations of Bulgarian racism should be tempered by the reality of a sport which still fell a long way short of the 'race equality and equal opportunity' patriotism of new media consensus. 'Sadly, because of their experiences in our own country', Southgate, reflecting on his post-match conversations with Bings, Sterling and Rashford, told the press, 'they are hardened to racism. I don't know what that says about our society but that's the reality (Hytner 2019). Olusoga's (2019) assessment was that: 'Southgate showed what leadership looks like. Diverting the attention away from himself and on to his players, he took the path of most resistance, and invited the English game to look at itself in the mirror.'

In this sense, then, the Southgate narrative has challenged an unreflective, selfcongratulatory, 'post-racist' New Englishness, taking a more nuanced view, for example, of the 1990s. As Goldblatt (2014) writes of the period:

...(although) the presence of black players in the (England) squad made the team a poor place for expressing a racist political nationalism, it wasn't immediately clear that it made Englishness more appealing to the country's minorities.

\section{Discussion and Conclusion}

The imagined community posited by Anderson and developed by Billig seems to imply a unitary nationalism. As we are concerned with the contribution made by sport and its accoutrements to the banal nationalism of the imagined community it behoves us to recognise MacClancy's $(1996,4)$ argument that 'sport is not intrinsically associated with a particular set of meanings or social values' but is rather 'an embodied practice in which meanings are generated, and whose representation and interpretation are open to negotiation and contest'. In 2004 Crabbe argued that, despite hopes that football would be part of a socially inclusive nationalism, 'Englishness' continued to be performed in culturally exclusive ways. Today there remains an element of football fandom that continues to deny the multi-cultural nature of England and its football team. This is reflected in their songs, flags, memes, jokes and language. For some time, sport scholars have argued that sport is both a site of repression and of resistance for participants from minoritized ethnicities (e.g. Long et al. 1997; Carrington 1998b). Sport/football events similarly offer the opportunity to resist the multi-cultural image increasingly projected by footballing authorities and assert a more 'traditional' idea of nationalism. Just as we 
have illustrated such contestations in relation to Beckhamisation they are likely to continue to play out, albeit in a different form under Southgatism

It would be a stretch to elevate Southgate's championing of his diverse, multicultural squad as representative of a new "sense of common purpose" as a deliberate attempt to disassociate the national team's identity from the ethno-nationalist aspects of the Nessun Dorma/It's Coming Home era. Southgate, himself, is of course a product of those times. His trajectory, first as a player and then a manager has, however, allowed him to understand the disillusionment felt towards that era, both on and off the pitch. On the pitch, the entitled Golden Generation of Beckham, Ferdinand, Lampard et al. had been exposed as a mirage. The 2010 World Cup defeat by Germany was, in the eyes of Perryman (2016), English football's version of Suez as the nation was brought down to earth with a thump.

Similarly, off the pitch, the rebranding of the New Labour/Cool Britannia era has long since unravelled, equally unceremoniously brought down to earth by Brexit populism. The 2016 Leave vote in the UK, fuelled by the disillusionment felt towards the Blairite project, has produced upheaval, polarisation and a pivoting away from an unreflective, complacent, supposedly classless vision of national renewal. The Southgate narrative can be seen, perhaps, as a rejection of both the triumphalism and defeatism of the previous era. Southgate has built a national team in his own image: modest, self-deprecating, down to earth, diverse and progressive. In the absence of an 'official' England song what might represent Southgatism? Setting aside the need for fans to have a catchy hook line, we suggest that something from that progressive patriot, Billy Bragg (2006), might be suitable. 'Half English'9 celebrates a multi-cultural England, though Bragg himself (personal communication) suggested 'Jerusalem'.

So can Southgatism change the way that the flag of St George and other contributors to the forging processes of banal nationalism in a way that was not fulfilled post-1996, or will the previous association with bigotry, racism and xenophobia continue to be a power in the construction of Englishness? Hundal (2018) wrote that 'England is crying out for a more inclusive and unified sense of identity... Football may not be loved by everyone but it did a better job of unifying us than our politicians have been doing lately.' Whether this latest attempt to create an inclusive and forward-looking identity succeeds in a country bitterly divided by Brexit remains to be seen. It may take some time for the processes of banal nationalism to change to the construction of a more progressive patriotism. As Billig $(1995,175)$ asserts, 'national identities are rooted within a powerful social structure, which reproduces hegemonic relations of inequity'. For Southgatism to gain purchase and generate a progressive patriotism that is a more racially inclusive national identity, it clearly has to be about more than Southgate himself and generate a web of everyday micro-messages.

\section{References}

Anderson, B. 1983. Imagined Communities: reflections on the origin and spread of nationalism. London: Verso. 
Aughey, A. 2007. The Politics of Englishness. Manchester: Manchester University Press.

Bairner, A. 2001. Sport, nationalism, and globalization: European and North American perspectives. Albany: State University of New York Press.

Bairner, A. 2015. Assessing the sociology of sport: on national identity and nationalism. International Review for the Sociology of Sport 50 (4-5): 375-379. doi: $10.1177 / 1012690214538863$

Billig, M. 1995. Banal nationalism. London: Sage.

Booth, R. 2019. Racism rising since Brexit vote, nationwide study reveals. The Guardian, 20th May. https://www.theguardian.com/world/2019/may/20/racism-onthe-rise-since-brexit-vote-nationwide-study-reveals

Braginsky, D. 2014. Dmitry Shostakovich, sport and politics in the USSR. Sport in Society 17 (3): 345-357. doi: 10.1080/17430437.2013.810423

Brentin, D. and L. Cooley. 2015. Nationalism and sport: a review of the literature. Studies on National Movements 3.

http://snm.nise.eu/index.php/studies/article/view/0306s/33

Campbell, T. and H. Khaleeli. 2017. Cool Britannia symbolised hope - but all it delivered was a culture of inequality. The Guardian, 5 July.

https://www.theguardian.com/inequality/commentisfree/2017/jul/05/cool-britanniainequality-tony-blair-arts-industry

Carrington, B. 1998a. 'Football's Coming Home' But Whose Home? And Do We Want It? In Fanatics! power, identity, and fandom in football edited by Adam Brown, 101-123. London: Routledge.

Carrington, B. 1998b. Sport, Masculinity and Cultural Resistance. Journal of Sport and Social Issues 22 (3): 275-298. doi: 10.1177/019372398022003004

Carrington, B. 1999. Too many St George Crosses to bear. In The Ingerland Factor: Home Truths from Football edited by M. Perryman, 71-86. Edinburgh: Mainstream.

Carrington, B. 2004. Introduction: Race/Nation/Sport. Leisure Studies 23 (1): 1-3. doi: $10.1080 / 0261436042000182272$

Cowley, J. and K. Shaw. 2019. The English Question. New Statesman, 27th November. https://www.newstatesman.com/politics/uk/2019/11/english-question

Crabbe, T. 2004. englandfans - A New Club for a New England? Social inclusion, authenticity and the performance of Englishness at 'home' and 'away'. Leisure Studies 23 (1): 63-78. doi: 10.1080/0261436042000182326

Curtis, N. 2019. Review of 'Don't Look Back in Anger: The Rise and Fall of Cool Britannia' by Daniel Rachel. Evening Standard, 19 September.

https://www.standard.co.uk/lifestyle/books/dont-look-back-in-anger-the-rise-and-fallof-cool-britannia-by-daniel-rachel-review-a4240981.html 
Derbyshire, J. 2018. England sees itself reflected in a young and diverse group of football players. Financial Times, June 22.

Doward, J. 2018, A nation hungry for joy finds new heroes in England's World Cup stars. The Observer, 7 July. https://www.theguardian.com/global/2018/jul/07/worldcup-england-squad-harry-maguire-yorkshire-sheffield-heroes

Duke, V. and L. Crolley. 1996. Football, Nationality and the State. London: Addison Wesley Longman.

Edensor, T. 2002. National identity, popular culture and everyday life. Oxford: Berg.

Garland, J. 2004. The Same Old Story? Englishness, the tabloid press and the 2002 Football World Cup. Leisure Studies 23 (1): 79-92. doi:

10.1080/0261436042000182335

Gibbons, T. 2011. English national identity and the national football team: the view of contemporary English fans. Soccer \& Society 12 (6): 865-879. doi:

10.1080/14660970.2011.609685

Gilroy, P. 1987. There Ain't No Black in the Union Jack. London: Hutchinson.

Giulianotti, R. 1999. Football: a sociology of the global game. Cambridge: Polity.

Goldblatt, D. 2014. How the England football team came to embody Englishness.

The Guardian Long Read, $23^{\text {rd }}$ October.

https://www.theguardian.com/news/2014/oct/23/-sp-how-england-football-teamcame-embody-englishness

Hamilton, I. 1993. Gazza Agonistes. Granta 45. https://granta.com/products/granta45-gazza-agonistes/

Hearn, J. 2007. National identity: banal, personal and embedded. Nations and Nationalism 13 (4): 657-674.

Hill, J. 1999. Cocks, Cats, Caps and Cups: A Semiotic Approach to Sport and National Identity. Sport in Society 2(2): 1-21.

Hundal, S. 2018. England may have lost but it gave us a sense of unity our political leaders have failed to do. Open Democracy, 17 July.

https://www.opendemocracy.net/en/opendemocracyuk/england-may-have-lost-but-itgave-us-sense-of-unity-our-political-leaders-have-faile/

Hytner, D. 2019. Gareth Southgate praises England players for making 'major statement'. The Guardian, 15 October.

https://www.theguardian.com/football/2019/oct/14/gareth-southgate-englandbulgaria-major-statement-racism

Jones, J. 2019. England fans sing 'Who put the ball in the racists' net?' as Mings and Sterling targeted by vile racism in Bulgaria. The Sun, 15 October.

https://www.thesun.co.uk/sport/football/10137205/england-fans-sing-racists-netmings-sterling-targeted-bulgaria/ 
Katwala, S. 2019. Be proud of our response to racist Bulgarian fans, but remember we've got our own issues. New Statesman, 15 October.

https://www.newstatesman.com/politics/sport/2019/10/be-proud-our-response-racistbulgarian-fans-remember-weve-got-our-own-issues

Kersting, N. 2007. Sport and national identity: a comparison of the 2006 and 2010 FIFA World CupsTM. Politikon 34 (3): 277-293. doi: 10.1080/02589340801962551

Kuper, S. 2018. Gareth Southgate is the perfect loser, which makes him the ideal England manager. New Statesman, 13 May.

https://www.newstatesman.com/politics/sport/2018/05/gareth-southgate-perfectloser-which-makes-him-ideal-england-manager

Kytö, M. 2011. 'We are the rebellious voice of the terraces, we are Çarşı':

constructing a football supporter group through sound. Soccer and Society 12 (1): 77-93. DOI: 10.1080/14660970.2011.530474

Lawton, J. 2013. David Beckham has taken more credit for himself than anyone else could give. The Independent, 18 May.

https://www.independent.co.uk/sport/football/news-and-comment/james-lawtondavid-beckham-has-taken-more-credit-for-himself-than-anyone-else-could-give8621852.html

Long, J. 2013. Opera Man and the Meeting of 'Tastes'. In Fields of Vision: The Arts in Sport, edited by D. Sandle, J. Long, J. Parry and K. Spracklen, 73-84. Eastbourne: Leisure Studies Association.

Long, J., B. Carrington and K. Spracklen. 1997. 'Asians Cannot Wear Turbans in the Scrum': explanations of racist discourse within professional rugby league. Leisure Studies 16 (4): 249-259. doi: 10.1080/026143697375322

MacClancy, J. 1996. Sport and Identity: an introduction. In Sport, Identity and Ethnicity, edited by J. MacClancy, 1-20. Oxford: Berg.

Machell, B. 2018. Rio Ferdinand: 'My generation killed the England football team'. The Times, $12^{\text {th }}$ May.

Miller, K. 1990. On the 1990 World Cup. London Review of Books 12 (14).

https://www.Irb.co.uk/the-paper/v12/n14/karl-miller/diary

New Statesman. 2018. Gareth Southgate and the new progressive Englishness.

New Statesman, $4^{\text {th }}$ July.

https://www.newstatesman.com/politics/sport/2018/07/gareth-southgate-and-newprogressive-englishness

Olusoga, D. 2019. At least England's footballers lead by example in the face of racism. The Guardian, 20 October.

https://www.theguardian.com/commentisfree/2019/oct/20/at-least-englandfootballers-lead-by-example-in-the-face-of-racism

Onuora, E. 2015. Pitch Black. London: Biteback. 
O'Toole, F. 2018. Heroic Failure: Brexit and the Politics of Pain. London: Apollo.

Parker, G. 2008. Power Games. Financial Times, March 7.

Perryman, M. 2016. 1966 and Not All That. London: Repeater.

Ronay, B. 2019. Paltry fines and spineless words helped create the poison in Sofia. The Guardian, 15 ${ }^{\text {th }}$ October. https://www.theguardian.com/football/2019/oct/15/uefapaltry-fines-sofia-bulgaria-england

Rosser, J. 2018. World Cup squad represents 'modern England' and can impact beyond football, says Gareth Southgate. Evening Standard, $26^{\text {th }}$ June.

https://www.standard.co.uk/sport/football/worldcup/world-cup-squad-representsmodern-england-and-can-impact-beyond-football-says-gareth-southgatea3872761.html

Spracklen, K., S. Timmins and J. Long. (2010) The Glory of Their Times: black rugby league players, imagined communities and the invention of tradition. In Recording Leisure Lives: sports, games and pastimes in 20th century Britain, edited by Snape, R. and H. Pussard, 139-153. Eastbourne: LSA.

Skey, M. 2009. The National in Everyday Life: a critical engagement with Michael Billig's thesis of Banal Nationalism. The Sociological Review 58 (2): 331-364. doi: 10.1111/j.1467-954X.2009.01832.x

Turner, Mark. 2013. Modern 'live' football: moving from the panoptican gaze to the performative, virtual and carnivalesque. Sport in Society 16 (1): 85-93.

Westall, C. 2016. Memories are Made of This. In 1966 and Not all That, edited by Mark Perryman. London: Repeater.

Williams, J. 2018. England fans sing 'football's coming home' - but where is 'home' really? The Conversation https://theconversation.com/england-fans-singfootballs-coming-home-but-where-is-home-really-99479

\footnotetext{
${ }^{1}$ England's Grand: https://www.itv.com/presscentre/ep1week46/englands-grand

2 The 'Three Lions' on the shirt derive from the royal coat of arms, a reference to Richard the Lionheart, and is the badge adopted by the Football Association.

${ }^{3} \mathrm{~A}$ few years later David Cameron, then prime minister, was similarly humiliated when not knowing whether it was Aston Villa or West Ham that he supported.

${ }^{4}$ Subsequently denied by Taylor in an interview with The Independent:

https://www.independent.co.uk/sport/football/news-and-comment/graham-taylor-told-by-fa-not-to-pick-toomany-black-players-during-time-as-england-manager-10230269.html

${ }^{5}$ Reported in The Guardian, 23 April 1993.

${ }^{6}$ In this he seems to be following Anderson's $(1983,137)$ more general argument regarding colonial nations.

${ }^{7}$ Quoted in Evening Standard, 26 June 2018.

${ }^{8}$ What could be more English than a waistcoat? But a waistcoat without a jacket?

${ }^{9}$ The lyrics can be found at: https://www.lyrics.com/lyric/5355388/Billy+Bragg/England\%2C+Half+English
} 